\title{
Empowering Indonesian Teachers to Improve Students' Learning: Case Studies of Teachers' Action Research
}

\author{
Umi Tursini \\ English Education Department, Universitas Kanjuruhan Malang, East Java, Indonesia
}

\begin{abstract}
This current study was undertaken to examine how Indonesian teachers implemented action research (AR) in an attempt to develop their professionalism and provide better learning opportunity for their students. The research approach in this study included qualitative case study design elements that involved three English teachers who varied in terms of teaching experience, age, and academic qualification as the research participants. The research participants were assisted to get more understanding about AR by inviting them to take part in AR workshops, participate in focus group discussions, and undertake an AR project. Multiple data sources were obtained through interview, observation, focus group discussion, and documentation. The findings indicated that all participants learned important things about their teaching practice and students' learning through their engagement in action research activity. The findings also showed that conducting AR had encouraged participants to be more reflective and empowered them to be a researcher of their own classroom. In spite of the positive and promising results of this study, the success of action research mainly depends on teachers' own need and motivation to conduct AR to monitor their teaching. Therefore, sufficient support should be provided to teachers to enable them to conduct AR including focus group discussions since this study also highlights the importance of collegial dialogues in developing teachers' practice. It is reasonable to recommend educational or institutional leaders in Indonesia provide opportunities for teachers to take initiative in referring to action research for achieving professional growth.
\end{abstract}

Index Terms - empower, student's learning, case study, teachers' professional development, action research, focus group discussion

\section{INTRODUCTION}

Teachers have a vital role in school improvement and educational change because they make a significant contribution to the quality of education provided to students. They directly facilitate learning opportunities to students and the nature of these opportunities impact the extent and rate of student learning. In other words, the quality of teachers is a key determinant of variation in students' academic outcomes (Darling-Hammond, 2000; Ferguson \& Ladd, 1996; Wenglinsky, 2000). It is therefore necessary for teachers to devote time to improving the quality of their instructional practice to promote effective teaching that helps students to better learn and grow (Tuckman, 1995).

In Indonesia context, one of teacher professional development activities is introduced through the Musyawarah Guru Mata Pelajaran (teacher association of subject teaching), known as MGMP. It is the activity of teachers' focus group discussion to specifically develop standardized concepts and the assessment of subjects (Saondi \& Suherman, 2010, p.75). It is usually conducted every month. However, this activity is still limited to discussions on teaching preparations such as lesson plan, syllabus, or examination material. Teachers do not have ample opportunity to get ideas about particular ways to maximize students' learning. Therefore, it is necessary for Indonesian teachers to take part in other professional development activities with the purpose of improving the quality of their instruction practice.

Conducting action research (AR) is a viable option for teacher professional development to provide better learning opportunity for students. It can be defined as a valuable way to extend teachers' teaching skills and gain more understanding of themselves as teachers, their classroom, and their students (Burns, 2010, p.1). According to Mills (2007, p. 5), AR is "any systematic inquiry conducted by teacher researchers, principals, school counsellors, or other stakeholders in the teaching/learning to gather information about how their particular schools operate, how they teach, and how well their students learn...". In other words, within the AR process, teachers study their own teaching and student learning with the aim of doing reflection on their teaching. That is looking back what has worked and has not worked in the teaching and thinking deeply about the strategies to enhance their teaching skill and students' learning. This is in line with what Ferrance (2000, pp.2-3) said that teachers involved in AR are "not problem-solving in the sense of trying to find out what is wrong, but rather a quest for knowledge about how to improve". Therefore, the goal of AR is to better understand and improve teachers' instructional practice and "engage in a process of continuous improvement" (Patthey \& Thomas-Spiegel, 2013, p. 482).

According to Hagevik, R., et al (2009), action research is a series of cycles that include describing a problem, seeking knowledge from previous investigators, collecting data, devising and implementing a strategy to change, evaluating the 
results, and planning for another cycle of improvement. In addition, Ferrance (2000, p. 2) stated that teachers who conduct AR begin a cycle of asking questions, collecting data, and acting upon what they learn in their research. This implies that AR involve a dynamic and integrated spiral process so that teachers may take the cycles as they need to find out what works best in their particular class situation.

Although action research has been around since the 1950s (Kayaoglu, 2015), this notion was officially introduced in the Indonesia context in 1995 through the Pendidikan Guru Sekolah Menengah Project (Roshsantingsih, 2004). It means AR has been initiated since 21 years ago in Indonesia. However, there is little evidence that Indonesian teachers have undertaken AR as a valuable way to enhance their professionalism. Some teachers are familiarized with AR through educational seminar and workshops but only a few teachers apply it in their classroom. This is because of some challenges, which hinder them from pursuing AR such as teachers' unfamiliarity with the concept of AR, insufficient opportunity and support from the institution, teachers' heavy workloads, and large size classes (Wallace, 1998). Moreover, the availability of AR activity itself depends highly on the institution (Rochsantingsih, 2004). Therefore, Indonesian teachers should have awareness and be provided with support to undertake AR.

Relevant studies have recommended the implementation of action research and associated it with teaching improvement and professional development. Rochsantiningsih (2004) conducted an AR to investigate Indonesian teachers' perceptions of the impacts of AR on their professional development. The findings suggested that teachers were able to improve many aspects of their classes and shift from being technicians and more into decision makers. In addition, Hagevik, et al (2012) conducted a study about the role of AR in promoting critical reflective thinking with the participants of twenty pre-service teachers engaged in a year-long middle level program. The findings indicated that AR engaged pre-service teachers in inquiry into their own practice. It also promoted critical reflection in a collaborative learning environment and was also a means to reflect upon and determine ways to change their teaching practices. Furthermore, Kayaoglu (2015) examined whether AR is a viable option for teachers in Turkey to carry out for their professional development. The findings showed that teachers had positive response about AR and were able to overcome some inadequacies in their educational environment.

As stated previously that not many Indonesian teachers have experience in undertaking action research. Therefore, the main focus of the present study was engaging three English teachers from two different schools in Indonesia in AR activity. The researcher facilitated them to employ $\mathrm{AR}$ in their classroom as one form of teacher professional development activities without sacrificing their teaching schedule because AR could be interwoven during teaching. It means the research participants were themselves involved in carrying out AR in their genuine teaching settings. Specifically, this current study was undertaken to examine how Indonesian teachers implemented AR in an attempt to develop their professionalism and provide better learning opportunity for their students.

To allow for a comprehensive understanding, two research questions were set out for the study:

1. What and how was AR implemented in Indonesian teachers' classroom?

2. What did teachers think about the AR process in relation to their teaching and students' learning?

\section{MEthodology}

\section{A. Research Design}

The research approach in this study included qualitative case study design elements because this design is ideal for understanding and interpreting observations of educational phenomena (Merriam, 1998). The educational phenomenon examined in this study was the implementation of AR by Indonesian teachers and the ways AR assisted them to develop their professionalism. Case study is defined as "an empirical study that investigates a contemporary phenomenon in depth and within its real-life context, especially when the boundaries between phenomenon and context are not clearly evident" (Yin, 2009, p. 18). Accordingly, an in-depth analysis of teachers' implementation of AR was conducted. In addition, as stated by Merriam (1998, p. 1), "research focused on discovery, insight, and understanding from the perspectives of those being studied offers the greatest promise of making significant contributions to the knowledge base and practice of education". Hence, this study employed a qualitative case study approach, that is, a case study of Indonesian teachers trying to improve their instructional practice through AR.

\section{B. Instruments}

Four data collection tools were used in this study: interview, observation, focus group discussion, and documentation. Yin (2009) considers interviews to be one of the most important sources of case study information. The participants were interviewed using semi-structured interview twice: (1) after they took part in focus group discussion for two times to ask about their AR preparation; and (2) at the end of the study to ask about how AR was conducted in their classroom and their perceptions about the AR process as related to their teaching and students' learning. All the interviews were recorded and later transcribed. Observations were done once in every participant's class when the action research was being implemented, whereas focus group discussion was conducted four times. Documentation used for this study included summary of teacher's AR, lesson plan, and teaching materials.

\section{Participants}

Participants in this study included three English teachers who varied in terms of teaching experience, age, and 
academic qualification. In addition, all participants had no prior knowledge about action research. Table 1 summarises the key detail pertaining to the participants in this study.

TABLE I.

RESEARCH PARTICIPANTS - KEY DETAILS

\begin{tabular}{|c|c|c|c|c|c|c|}
\hline Name & Gender & Age & $\begin{array}{l}\text { Teaching } \\
\text { experience }\end{array}$ & $\begin{array}{l}\text { Academic } \\
\text { qualification }\end{array}$ & Teaching place & $\begin{array}{l}\text { Class used for } A R \\
\text { focus of Teaching }\end{array}$ \\
\hline Teacher A & Female & 23 years & 1 year & Undergraduate Degree & Private school & $\begin{array}{l}\text { Year } 7 \\
\text { Pronunciation }\end{array}$ \\
\hline Teacher B & Female & 48 years & 27 years & Master Degree & Public school & $\begin{array}{l}\text { Year } 8 \\
\text { Speaking }\end{array}$ \\
\hline Teacher C & Female & 48 years & 21 years & Undergraduate Degree & Public school & $\begin{array}{l}\text { Year } 9 \\
\text { Speaking }\end{array}$ \\
\hline
\end{tabular}

From the details presented in the above table, it is evident that the participants had various backgrounds and experiences. All the teachers were female. Among them, teacher B held a master degree. One teacher was a novice teacher who just recently obtained his/her undergraduate degree and was teaching at a private school. On the other hands, the other two teachers were experienced teacher who had been teaching for more than 20 years and were teaching at a public school. The class used for AR focus of teaching varied from year 7 up to year 9.

\section{Data Collection and Analysis}

Data in this study were collected over a six-month period. The researcher assisted the research participants to get more understanding about AR by inviting them to take part in two workshops. The workshops focused on equipping the research participants with necessary information about AR so that teachers felt emboldened to conduct their own research in their classrooms. To help them to complete their AR, the researcher also facilitated them to take part in the activity of Focus Group Discussions (FGD) with other participants. These FGD were as a means for the research participants to share their issues in their classroom, their AR, or the difficulties in conducting AR. In summary, the research strategy consists of a three-step sequence: introducing to action research, familiarizing with action research practices in the field, and facilitating teachers to embark on their action research. The entire data collection process is summarized in Table 2 below.

TABLE II.

STEPS IN THE RESEARCH SEQUENCE

\begin{tabular}{|c|c|}
\hline Activity & Focus \\
\hline Workshop 1 & $\begin{array}{l}\text { This workshop was intended to introduce action research to the participants including } \\
\text { its features, models, benefits of AR to education, and researchable issues in AR. }\end{array}$ \\
\hline Workshop 2 & $\begin{array}{l}\text { In this workshop, the participants were facilitated to get more understanding } \\
\text { aboutAR by giving more examples of AR projects and its reports. }\end{array}$ \\
\hline Focus Group Discussion 1 & $\begin{array}{l}\text { This discussion facilitated teachers to identify some researchable issues in their } \\
\text { classroom by sharing their problems in teaching learning process to other } \\
\text { participants. The participants could then decide a topic for their AR. }\end{array}$ \\
\hline Focus Group Discussion 2 & $\begin{array}{l}\text { This dicussion focused on the preparation of each participant to take part in AR in the } \\
\text { classroom. The participants were encouraged to express ideas or feedback about } \\
\text { other participants' AR plan. }\end{array}$ \\
\hline Interview & $\begin{array}{l}\text { This interview was conducted after the research participants took part in FGD for two } \\
\text { times. Its focus was to get information about their preparation in undertaking AR. }\end{array}$ \\
\hline Class observation & $\begin{array}{l}\text { Class observation was conducted in every participant's class when she was } \\
\text { implementing AR with the objective to observe what happened in the class. The } \\
\text { researcher then gave some suggestions related to every participant's AR. }\end{array}$ \\
\hline Focus Group Discussion 3 & $\begin{array}{l}\text { This discussion was used to share every participant's AR that had been conducted. } \\
\text { New feedback and ideas about how to improve or what needed revising in every } \\
\text { participant's AR became the focus of this discussion. }\end{array}$ \\
\hline Focus Group Discussion 4 & $\begin{array}{l}\text { This last discussion was conducted after the participants accomplished their AR. It } \\
\text { was used by participants to present their AR and shared the summary of their AR to } \\
\text { others. }\end{array}$ \\
\hline Interview & $\begin{array}{l}\text { This interview was conducted at the end of the study to ask about how AR was } \\
\text { implemented in their classroom and their perceptions about the AR process as in } \\
\text { relation to their teaching and student's learning. }\end{array}$ \\
\hline
\end{tabular}

The researcher used case analysis to analyze the results of interview by focusing on the responses of each research participant (Patton, 1980) with the purpose to understand how every participant's opinions differed during the term, not to reach a common truth among interviewees. Because the interviews were conducted in Indonesian, they were all translated into English and subsequently transcribed. In this study, the researcher acted as the translator of the transcriptions so that there was an opportunity to check the validity of interpretations and for "close attention to cross cultural meanings and interpretations and potentially brings the researchers up close to the problems of meaning equivalence within the research process" (Ferguson \& Ladd, 1996, p. 168).

Furthermore, the data from observation and documents were analyzed using the content analysis method. First, they were carefully sorted and coded and then categorized based on the research questions. Next, frequency of each code 
was counted to identify prominent themes. Following the completion of these steps of analysis, a cross-case analysis was initiated to identify similarities and differences. As a result, themes emerged from the data with no predetermined theoretical assumptions.

\section{RESULTS}

The organization of the findings of this study comprises two main sections: the implementation of AR in teachers' classroom and teachers' perception about the AR process in relation to their teaching and students' learning.

\section{A. The Implementation of AR in Teachers' Classroom}

As stated previously that all research participants in this study had no prior experience in undertaking action research in their classroom although two of them had been teaching for more than 20 years. After they became quite familiar with the spirit and stages of action research by joining the workshops, they came up with certain problems or concerns to focus on, as presented in Table 3 below.

TABLE III.

TEACHERS' CONCERN FOR ACTION RESEARCH

\begin{tabular}{ll}
\hline Name & Focus on AR \\
\hline Teacher A & Students' lack of basic pronunciation \\
Teacher B & Students' speaking in agreement and disagreement expression \\
Teacher C & Students' speaking skill in expressing opinion \\
\hline
\end{tabular}

As shown in the above table, all participants' AR topics covered improving teaching practices and overcoming problems in the class. In other words, they were interested in the topics of learning rather than teaching. This is in line with the views of Richards and Lockhart (1994) who argued that the purpose of AR is to make changes and to make improvement to the current teaching and learning. In this study, all teachers focused on making improvement in their students' learning. They were able to identify a problem to their everyday teaching as stated by Teacher A in the excerpt below:

I could see clearly that the biggest problem in my class was the students' pronunciation. They could not pronounce the words correctly. I think I need to focus more on how to help them to improve their pronunciation.

Similarly, when Teacher B was asked about the existing problems in her problem that needed to be solved, she stated:

I found that the overall situation of my class was as not really favorable. The students were reluctant and not motivated to participate in the class activity. Moreover, when I taught them about expressing agreement and disagreement, some students did not able to do that.

Furthermore, Teacher $\mathrm{C}$ raised the issue of passive students in her class as presented in the below excerpt:

I had a heterogeneous class in which the students had various level of English speaking ability. Some students were very dominant and active, while others were very quiet and passive in the class. I had to find a solution. I think I need to use appropriate teaching method to encourage the passive students to participate in class activity as well. When I delivered a material about expressing opinions, only few students were able to do that. Most students were passive.

After all research participants decided the focus of their AR, they then designed a plan of action they intended to take. Teacher A decided to use tongue twister to practice and improve her students' pronunciation and fluency as written in her AR summary of AR.

I gave a short passage for my students to read. I then more realized that many students made errors in pronouncing the words. After joining FGD activity, my colleagues suggested me to apply tongue twister to solve my students' problem. I would use it in my class. I would find the material on the Internet and YouTube and used a voice-recorder to see their improvement.

Another teacher who was aware that she needed to improve her students' speaking decided to use problem-solving strategy. This strategy was particularly implemented to assist students in agreement and disagreement expressions as she wrote in her summary of AR:

When the first time I gave the material about expressing agreement and disagreement, I was not really happy with the students' response. I thought I needed different teaching technique to help them. I then came up with problem-solving strategy after taking part in FGD activity. I would prepare some problems to solve in flashcards.

Complaining of not having a homogeneous class, teacher $\mathrm{C}$ decided to use role-play technique to create a cooperative atmosphere in her class so that every student would contribute in the class activity. He wrote in his/her summary of AR as follows:

I wanted my students to cooperate with their friends so that the students who were passive would be encouraged to be active. I thought the use of role-play in my speaking class might help. First, I would teach them about expressing opinions in English. Next, I would prepare cards written with particular situations and ask them to perform a role-play based on the situation in the card. 
After making some plans in their AR, the research participants then started to implement their AR project. Teacher A reported:

I wrote the full version of the tongue twister in the whiteboard and asked the students to write it on their notebook. Before reading it, I explained the students what the tongue twister was about. Then, I read the first verse the tongue twister for them slowly and they repeated it. I continued this until the last verse. At the end of the session, the students had to read the full verse of tongue twister and I recorded them.

Teacher B implemented the problem-solving strategy in her speaking class. She asserted:

After explaining how to express agreement and disagreement in English, I asked every student to take one card and expressed the solution of the problem in the card. I asked every student to come forward to share his or her solution in front of the class.

How teacher C implemented the role-play technique in her speaking class to help students' ability in expression opinion is found in the excerpt below.

Firstly, I gave the material about expression opinions in English. I then asked the students to express their opinion by providing cards. The students formed a group of 3 students. One student from each group took one card and the group needed to perform a role-play about the situation written in the card in front of the class.

After implementing their AR, research participants did the observation and reflection. Teacher A stated that she needed to do the second cycle in her AR as presented in the following excerpt:

The students looked excited because of the repetition of the words, and got confused with how the words and pronounced especially when the order of the words changed. It was not sufficient if the students only learn how to pronounce words only from me, as I am not a native speaker. It would be better to let them hear how native speakers pronounced some words, to familiarize them with how native speakers spoke and to better practice some words. I would play an audio of Peter Piper recited as a fun song from YouTube by a native speaker with varied speed from slow to fast, and asked them to sing along in the next meeting.

Teacher B also reported that she needed to do the second cycle since she was not really content with the outcome of her AR. She reported:

When I required the students to take one card and express their agreement/disagreement about the provided topics, they looked motivated. However, I thought that was not enough. I thought I still needed one more meeting to maximize their learning. I would prepare more flashcards with pictures and more interesting problems to solve. Next, I would ask my students to form a group of four. Each group would take one card and expressed their solution about the problems provided in the card by discussing with their friends in a group. The group representative then needed to share the solution to others.

Like teacher A and teacher B, teacher $\mathrm{C}$ also did the next cycle in her AR project to improve students' ability in expressing opinions as presented in the excerpt below.

I was happy since all students participated in role-play activity and could express their opinion quite well. However, some students did not talk fluently and stopped at the middle of conversation for a very long time. I thought I needed to give them more time to prepare their role-play. In the next meeting, I would ask them to prepare their own role-play about expressing opinion at home then presented it in the class.

\section{B. Teachers' Perception about the AR Process in Relation to Their Teaching and Students' Learning}

At the end the action research undertaken by the research participants, the researcher asked them to share their experience and overall outcome. All participants acknowledged that they AR had helped them to critically analyze their students' need and learning as stated by teacher A in the excerpt below.

My students' pronunciation increased well after I played tongue twister in the audio. They seemed more motivated. It caught students' attention well, made them focused, and was faster to make them understand. Eventually, students would be easier to remember how certain words were pronounced by native speakers as they had listened to it. I now realize that my students are more motivated to learn English from interesting media so that I will provide more interesting English videos for them.

Similarly, teacher B mentioned that her class was alive and the students were engaged in expressing their solutions for the provided problems as presented in the following excerpt.

My students engaged in the class activity so well. After I asked them to work in a group, they were motivated to discuss the solutions with their group. They provided interesting solutions, which encouraged other groups to give feedback. I know now that my students are happy with new teaching techniques. Usually I just followed the activity in the textbook. When I had a new class activity, they were much more excited to participate in the teaching and learning process. Initially, I thought that this AR was tiring and time-consuming since I was quite busy to prepare the teaching material and media such as flashcards and pictures. However, when I know that what I prepared for this AR encouraged my students a lot to take part more in my lesson, I felt so motivated as well to prepare more new class activities.

Furthermore, research participants indicated that action research boosted their self-confidence and inspired them to be more reflective and creative. Teacher A, for example reported that AR helped her to become, "...more aware of examining whether my teaching method was effective or not and whether my students were learning or not". Similarly, teacher C stated: 
The reflection at the end of my AR project showed that all students in my class were engaged in the class activity when I asked them to prepare and perform a role-play. In other words, I need a class activity, which facilitate all students to be active in teaching and learning process like role-play. The strategies I implemented in my AR had solved the problems I investigated. I'm now confident enough that I will be able to help students to better learn by providing more interesting and various class activities. That's why I will keep using more suitable activities for my students in the next class meetings.

\section{DISCUSSION}

This study facilitated all research participants to conduct AR for the first time. Although they sometimes felt it was time-consuming and hard due to overloaded teaching hours, they learned important things about their teaching practice and students' learning through their engagement in action research activity. Specifically, the participants reported that the improvements as a result of specific actions taken in their research included students' attitudes, involvement behaviors, and learning. This is consistent with the views of Guskey (2000) who stated that the ultimate goal of teacher professional development activity is to improve the students' learning so that they can achieve and perform better. Teacher $\mathrm{C}$, for example, reported that after implementing a role-play activity, the situation in the classrooms improved where students showed their increasing participation in the lessons. Learning became more enjoyable for the students. She then decided to change her current teaching practice to facilitate all students to be engaged in teaching and learning process by providing various activities. In other words, AR empowered teachers to try new teaching techniques and materials in order to enhance instructional practice as part of the process of change. This supports the views of Burn (1999) and Zeichner (2003) who stated that teacher AR brings real changes in the teachers, their classrooms, and their schools.

The findings of this study also showed that conducting AR had encouraged participants to be more reflective. They critically reflect on their existing practice with the aim of exploring new knowledge and understanding about their teaching and student leaning. This is in line with the views of Feldman (2002) and Zeichner and Liston (1987) who stated that through reflection on action, teachers became more thoughtful about teaching, aware of their practices and the effects that their teaching had on their students' thinking and learning. Initially, all participants questioned their students' problem in learning. They themselves then proposed a solution, implemented it and did reflection on it. For instance Teacher B said, "AR gave me the ability to look in-depth at my instructional practice and students' learning. I tried to find what worked and what did not."

Action research facilitated all research participants to choose the research topic and conduct it in their own classroom. In other words, they became the managers of their own research. This enhanced participants' self-confidence. Teacher A, for instance stated:

After joining the workshop, I was challenged to identify a problem in the classroom and implement a particular technique to solve it. That was a new experience for me. Initially, I was confused how to complete my AR. However, I became more familiar with AR after I joined focus group discussions with other participants. I felt AR increased my self-confidence.

This is consistent with the findings of Kayaoglu (2015) who reported that by participating in AR, "the teachers adopted a researcher role and investigative stance towards their own classroom practices. The shifts in roles from the teacher as operator to the teacher as problem-finder and solver boosted their self-confidence"(p. 155).

\section{CONCLUSIONS}

In this study, the researcher took the role as a facilitator to introduce research participants with action research by presenting workshops on AR and facilitated them to take part in focus group discussions and conduct their own AR project. The purposes were to examine how they implemented AR in an attempt to improve students' learning and explore their perception about the AR process in relation to their teaching and students' learning. In spite of the positive and promising results of this study, the success of action research mainly depends on teachers' own need and motivation to conduct AR to monitor their teaching. Therefore, sufficient support should be provided to teachers to enable them to conduct continuous action research including focus group discussions since this study also highlights the importance of collegial dialogues in developing teachers' practice. It is reasonable to recommend educational or institutional leaders in Indonesia provide opportunities for teachers to take initiative in referring to action research for achieving professional growth as "teachers are unlikely to develop a respect for their own experience and knowledge unless they can find wider support and acknowledgement for the value of their experience and understanding" (Loughran\& Northfield, 1996, p. 3). The necessary provisions must therefore be in place and will ideally include formal training or workshops on AR, the allocation of time to carry out the process, and ongoing support to address teachers' needs and concerns about the process in terms of consistency and timeliness.

The present study is limited in several ways. First, it was conducted in particular school in Indonesia. This project was also a small- scale study involving three English teachers. Hence, the findings should not be interpreted as a way to reveal the implementation of AR within the system of higher education in Indonesia. However, readers may find the similarities with their own contexts and see whether the findings and implications are relevant. Second, this study 
focused on a short-term examination (six months) of the implementation of AR. Therefore, further longitudinal study is needed into how teachers can sustain changes in their teaching practices that result from AR activity.

\section{REFERENCES}

[1] Burns, A. (1999). Collaborative Action Research for English Language Teachers. United Kingdom: Cambridge University Press.

[2] Burns, A. (2010). Doing Action Research in English Language Teaching: A Guide for Practitioners. New York: Routledge.

[3] Darling-Hammond, L. (2000). 'Teacher Quality and Student Achievement: A Review of State Policy Evidence'. Education Policy Analysis Archives, 8 (1), 1-49.

[4] Feldman, A. (2002) Existential Approaches to Action Research. Educational Action Research, 10(2), 233-252

[5] Ferrance, E. (2000). Action research. Providence, RI: Brown University.

[6] Ferguson, R. F., \& Ladd, H. F. (1996). 'How and Why Money Matters: An Analysis of Alabama Schools', Holding Schools Accountable: Performance Based Reform in Education. Washington DC: Brookings Institute.

[7] Guskey, T. R. (2000). Evaluating Professional Development. Thousand Oaks, California: Corwin Press Inc.

[8] Hagevik, Rita; Aydeniz, Mehmet; Rowell, C. Glennon. (2009). Action research to strengthen middle grades interns' reflective practitioners' skills: a case in point at a large state university. In paper presented at the 61st annual meeting of American association of colleges for teacher education, Chicago, IL.

[9] Hagevik, Rita; Aydeniz, Mehmet; Rowell, C. Glennon. (2012). Using Action Research in Middle Level Teacher Education to Evaluate and Deepen Reflective Practice. Teaching and Teacher Education: An International Journal of Research and Studies, 28(5), 675-684.

[10] Kayaoglu, M. (2015) Teacher researchers in action research in a heavily centralized education system, Educational Action Research, 23:2, 140-161.

[11] Loughran, J., \& Northfield, J. (1996). Opening the Classroom Door: Teacher, Researcher, Learner. London: Falmer.

[12] Merriam, S. B. (1998). Qualitative Research and Case Study Applications in Education, Revised and Expanded from "Case Study Research in Education”. San Fransisco: Jossey-Bass Inc.

[13] Mills, G. E. (2007). Action research: A guide for the teacher researcher (3rd ed.). Upper Saddle River, NJ: Pearson Merrill Prentice Hall.

[14] Patton, M. Q. (1980). Qualitative evaluation methods. Beverly Hills, CA: Sage.

[15] Patthey, G.G., \& Thomas-Spiegel, J. (2013). Action research for instructional improvement: The bad, the ugly, and the good. Educational Action Research, 21(4), 468-484.

[16] Richards, J.C., \& Lockhart., C. (1994). Reflective Teaching in Second Language Classrooms. Cambridge: Cambridge University Press.

[17] Rochsantiningsih, D. (2004). Enhancing professional development of Indonesian high school teachers through action research (Doctor of Philosophy Dissertation), Macquarie University, Australia.

[18] Saondi, O \&Suherman, A. (2010). Etika Profesi Keguruan. Bandung: PT Refika Aditama.

[19] Tuckman, B. W. (1995). Teacher Effectiveness: A Look at What Works. Peabody Journal of Education, 70 (2), 127-138.

[20] Yin, R. K. (2009). Case Study Research Design and Methods Fourth Edition. Thousand Oaks, California: SAGE Publications, Inc.

[21] Wallace, M. J., (1998). Action Research for Language Teachers. United Kingdom: Cambridge University Press.

[22] Wenglinsky, H. (2000). How Teaching Matters: Bringing the Classroom Back into the Discussions about Teacher Quality. Educational Testing Service. http://www.ets.org/research/pic/teamat.pdf. (accessed 20/2/2017).

[23] Zeichner, K.M. (2003). Teacher Research as Professional Development for P-12 Educators in the USA. Educational Action Research, 11(2), 301-325

[24] Zeichner, K., \& Liston, D. P. (1987). Teaching student teachers to reflect. Harvard Educational Review, 57, 23-48.

Umi Tursini, Ph.D is an English lecturer at the Faculty of Language and Literature, Universitas Kanjuruhan Malang, East Java, Indonesia. She earned his $\mathrm{PhD}$ from the University of New South Wales, Australia. Her research interests include teacher professional development, action research, and teaching speaking. 